\title{
Zinc- $\alpha 2$-glycoprotein: A proliferative factor for breast cancer? In vitro study and molecular mechanisms
}

\author{
LAETITIA DELORT $^{1,2^{*}}$, STÉPHANE PERRIER $^{1,2^{*}}$, VIRGINIE DUBOIS $^{1,2}$, HERMINE BILLARD $^{1,2}$, \\ TOMAS MRACEK ${ }^{4}, \mathrm{CHEN} \mathrm{BING}^{4}$, MARIE-PAULE VASSON $^{1-3}$ and FLORENCE CALDEFIE-CHÉZET ${ }^{1,2}$ \\ ${ }^{1}$ Clermont University, University of Auvergne, UFR Pharmacy, Laboratory SVFp, F-63000 Clermont-Ferrand; \\ ${ }^{2}$ INRA, UMR 1019, ECRIN, CRNH Auvergne, F-63000 Clermont-Ferrand; ${ }^{3}$ Centre Jean Perrin, \\ Nutrition Unit, F-63003 Clermont-Ferrand, France; ${ }^{4}$ Obesity Biology Research Unit, \\ School of Clinical Sciences, University of Liverpool, Liverpool L69 3GA, UK
}

Received October 31, 2012; Accepted January 4, 2013

DOI: 10.3892/or.2013.2311

\begin{abstract}
Zinc- $\alpha 2$-glycoprotein (ZAG) is a new adipokine whose gene expression is downregulated in obese patients. We recently reported ZAG expression in breast tumor or healthy breast tissue and detected this expression at high levels in ductal carcinoma and in normal epithelial adjacent tissue but not in normal tissue of healthy women. In the present study, we used two human breast tumor cell lines (MCF-7 and MDA-MB-231) and one fibrocystic breast cell line (MCF-10a) to examine whether recombinant ZAG has an effect on proliferative/ apoptotic response in breast cancer cell lines. ZAG seemed to exert a proliferative effect on breast cancer cell proliferation [+11 to $27 \%$ in MCF-7 with $(\mathrm{ZAG})=5-20 \mu \mathrm{g} / \mathrm{ml} ;+13 \%$ in MDA-MB-231 with $(\mathrm{ZAG})=5 \mu \mathrm{g} / \mathrm{ml}]$ and, on the contrary, an anti-proliferative effect in the fibrocystic breast cell line [-5 to $-8 \%$ in MCF-10a with $(\mathrm{ZAG})=5-10 \mu \mathrm{g} / \mathrm{ml}]$. ZAG was able to modulate gene and protein expression involved in the apoptotic response. However, further studies are required to fully elucidate the effects of ZAG on the proliferation of mammary cells.
\end{abstract}

\section{Introduction}

Obesity is related to several metabolic disorders such as type 2 diabetes mellitus, coronary heart disease and hypertension, and is associated with cancer development in different tissues including colon, prostate and breast (1). It has been clearly demonstrated that obesity is a risk factor for breast cancer development in postmenopausal women $(2,3)$. Moreover, an excess of adipose tissue favors breast cancer recurrence and is associated with higher mortality (4). Thus, overweight or obese

Correspondence to: Dr Laetitia Delort, Clermont University, University of Auvergne, UFR Pharmacy, Laboratory SVFp, 28 Place Henri Dunant, F-63000 Clermont-Ferrand, France

E-mail: laetitia.delort@udamail.fr

*Contributed equally

Key words: Zinc- $\alpha 2$-glycoprotein, breast cancer, proliferation, apoptosis women with breast carcinoma have a 2.5 -fold increased risk of mortality within five years of diagnosis compared with lean women (5). Numerous factors have been proposed to explain the relationship between obesity and breast cancer (6-8), however, none has been completely conclusive.

Emerging data suggest that adipose tissue, which is an endocrine organ producing a large range of factors, may interfere with cancer development. These factors, mainly secreted by the adipose tissue, known as adipokines, include angiogenic factors, paracrine mitogens and anti-mitogens, growth factors and pro-inflammatory cytokines (IL-1, TNF- $\alpha$ and IL-6) involved in the mediation or the coordination of inflammatory diseases and obesity $(9,10)$. Adipokines are produced by different fat depots, including subcutaneous, visceral and mammary adipose tissue. Of note, adipokines may act on breast tissue in an endocrine manner (via external adipose sources), in a paracrine pathway (via mammary adipose tissue secretion and non adipose sources including stromal cells and inflammatory cells) and in an autocrine manner (via the mammary tumor by itself). The structure of the mammary gland favors a close interaction between mammary adipose tissue and breast tissue, and suggests that adipokines produced by mammary adipose tissue and the tumor microenvironment may be the major link between obesity and disease progression and metastasis (11-14). We previously investigated simultaneously the in vitro and in vivo molecular mechanisms by which leptin induces and, conversely, adiponectin suppresses, tumor proliferation in breast cancer cells $(15,16)$. We suggested that these two adipokines have antagonistic properties in breast cancer development by modulating differentially both proliferative and apoptotic signaling pathways (17).

Zinc- $\alpha 2$-glycoprotein $(Z A G)$ is a new adipokine whose gene expression is reduced in subcutaneous fat of obese patients $(18,19)$. This expression is positively correlated with adiponectin expression and negatively correlated with leptin expression, suggesting a protective role for ZAG in breast cancer (20). ZAG is also a sound immunohistochemical marker of breast cell differentiation since ZAG tissue levels are associated with histological grades of tumors and vary from $4.6 \mu \mathrm{g} / \mathrm{mg}$ in well-differentiated tumors to $0.9 \mu \mathrm{g} / \mathrm{mg}$ in poorly differentiated tumors $(21,22)$. However, other studies 
found that circulating levels of ZAG are significantly higher in cancer patients $(51 \mathrm{mg} / \mathrm{l})$ as compared with levels in healthy women (44 mg/l), particularly in patients with advanced and node-positive breast cancer (23). Moreover, Bing et al (18) showed that ZAG expression is upregulated in mice with cancer cachexia. Overexpression in white adipose tissue of tumor-bearing mice suggests that ZAG plays a role in the substantial reduction of adiposity in cancer cachexia. ZAG is also considered a prognostic marker in breast cancer (24). We recently reported ZAG expression in breast tumor or healthy breast tissue and detected this expression at high levels in ductal carcinoma and in normal epithelial adjacent tissue, but not in normal tissue of healthy women (25). We also found ZAG expression was positively correlated to leptin receptor and negatively correlated to adiponectin receptor in cancer tissues. Our previous data suggested both a potential prognostic role for ZAG in breast cancer and a close interaction between ZAG and other major adipokine pathways.

The aim of the present study was to characterize the involvement of ZAG in breast cancer proliferation. Thus, we explored the in vitro potential effect of human recombinant ZAG on i) proliferative/apoptotic response, and ii) the modifications of gene expression in different breast epithelial cell lines.

\section{Materials and methods}

Cell culture. The human breast cancer cell lines MCF-7 and MDA-MB-231, and the human fibrocystic breast cell line MCF-10a were obtained from the American Type Culture Collection (ATCC). MCF-7 cells were routinely cultured in RPMI-1640 medium supplemented with $10 \%$ heat-inactivated fetal calf serum (FCS), L-glutamine $(2 \mathrm{mM})$ and gentamicin $(50 \mu \mathrm{g} / \mathrm{ml})$ at $37^{\circ} \mathrm{C}$ under a $5 \% \mathrm{CO}_{2}$ atmosphere. MDA-MB-231 cells were cultured in Leibovitz's L-15 medium with $15 \%$ heat-inactivated FCS, L-glutamine $(2 \mathrm{mM})$ and gentamicin $(50 \mu \mathrm{g} / \mathrm{ml})$ at $37^{\circ} \mathrm{C}$ in humidified conditions. MCF-10a cells were cultured in DMEM HAM's F12 medium supplemented with $10 \%$ heat-inactivated horse serum (HS), EGF $(0.02 \mu \mathrm{g} / \mathrm{ml})$, cholera toxin $(0.1 \mu \mathrm{g} / \mathrm{ml})$, hydrocortisone $(0.5 \mu \mathrm{g} / \mathrm{ml})$, insulin $(0.25 \mathrm{UI} / \mathrm{ml})$ and L-glutamine $(2 \mathrm{mM})$ at $37^{\circ} \mathrm{C}$ under a $5 \% \mathrm{CO}_{2}$ atmosphere (16).

Recombinant human ZAG (rh-ZAG). Recombinant human (rh)-ZAG was kindly provided by Mracek et al (20) (Obesity Biology Research Unit, School of Clinical Sciences, University of Liverpool) and its production was recently described.

Proliferation assay. The human mammary cell lines (MCF-7, MDA-MB-231 and MCF-10a) were seeded at the density of $5 \times 10^{3}$ cells in 96 -well plates in a complete medium. After $24 \mathrm{~h}$ of incubation, cells were washed with PBS and exposed to fresh medium (control) or to fresh medium containing different concentrations of rh-ZAG: $1.2,2.5,5,10$ and $20 \mu \mathrm{g} / \mathrm{ml}$. After $96 \mathrm{~h}$, cells were washed with PBS and incubated with $200 \mu \mathrm{l}$ of a $25 \mu \mathrm{g} / \mathrm{ml}$ solution of resazurin in RPMI-1640 medium for $2 \mathrm{~h}$ at $37^{\circ} \mathrm{C}$. Fluorescence was then measured on an automated 96-well plate reader (Fluoroskan Ascent FL; Thermo Fisher Scientific, Wilmington, DE, USA) using an excitation wavelength of $530 \mathrm{~nm}$ and an emission wavelength of $590 \mathrm{~nm}$.
Table I. Primers used in qRT-PCR assays.

\begin{tabular}{ll}
\hline BAG1 & F: 5'-CACAGCAATGAGAAGCACG-3' \\
BAG1 & R: 5'-GTGTTTCCATTTCCTTCAGAG-3 \\
BAG3 & F: 5'-ATGACCCATCGAGAAACTGC-3' \\
BAG3 & R: 5'-AATTGGGATGTGTCCAGGAG-3' \\
MX1 & F: 5'-AGCTCGGCAACAGACTCTTC-3' \\
MX1 & R: 5'-GGATGATCAAAGGGATGTGG-3' \\
TP53 & F:5'-GCGCACAGAGGAAGAGAATC-3' \\
TP53 & R: 5'-AGAGGAGCTGGTGTTGTTGG-3' \\
18S & F: 5'-GTCTGTGATGCCCTTAGATG-3' \\
18S & R: 5'-AGCTTATGACCCGCACTTAC-3' \\
\hline
\end{tabular}

F, forward; R, reverse.

Under these conditions, fluorescence was proportional to the number of living cells in the well (16). The cell proliferation assay was performed three times in triplicates for each concentration tested.

Analysis of gene expression. Total RNA was extracted with Trizol according to the manufacturer's recommendations (Invitrogen). The quantity and quality of RNA was assessed by $260 / 280$ ratio using a NanoDrop 8000 Spectrophotometer (Thermo Fisher Scientific). cDNAs were obtained with HighCap cDNA RT kit RNAse inhibitor (Applied Biosystems).

Real-time PCR assays of BAG1, BAG3, MX1, TP53 and $18 S$ mRNA expression levels were performed using the StepOne instrument (Applied Biosystems) with Power SYBR-Green (Applied Biosystems) following the manufacturer's instructions. The cDNAs were amplified using the primers summarized in Table I. The PCRs were set up in 48-well plates in a total volume of $20 \mu \mathrm{l}$ and $20 \mathrm{ng}$ of cDNA. The PCR conditions were as follows: $2 \mathrm{~min}$ at $50^{\circ} \mathrm{C}, 10 \mathrm{~min}$ at $95^{\circ} \mathrm{C}, 40$ cycles of $15 \mathrm{sec}$ at $95^{\circ} \mathrm{C}$ and $30 \mathrm{sec}$ at $62^{\circ} \mathrm{C}$.

The comparative cycle threshold (CT) method $\left(2^{-\Delta \Delta \mathrm{CT}}\right)$ was used to calculate the relative gene expression of ZAG-treated cells normalized within the sample to an endogenous reference gene (18S), and relative to the expression of the same gene in untreated cells: $2^{-\Delta \Delta \mathrm{CT}}$ method with $\Delta \Delta \mathrm{CT}=[\Delta \mathrm{CT}$ (ZAG-treated cells) $-\Delta \mathrm{CT}$ (untreated cells) $]$ and $\Delta \mathrm{CT}=$ [CT (target gene) - CT (reference gene)]

Statistical analysis was performed using the paired Student's t-test. A P-value $<0.05$ was considered to indicate a statistically significant difference.

Western blotting. Cells lysates (containing $10 \mu \mathrm{g}$ of total proteins) were separated on 4-12\% SDS-PAGE gels (Invitrogen), transferred to nitrocellulose and blotted with various antibodies. We used primary antibodies (Santa Cruz Biotechnology, Inc.,) against the following proteins: p53 (DO-1), p21, Bax, c-Myc and cyclin D1. Secondary horseradish peroxidase (HRP)-conjugated antibodies were obtained from Santa Cruz Biotechnology, Inc., (anti-rabbit) or Dako (anti-mouse). Immunoreactive bands were visualized by incubation with DURA Western blotting detection system from Thermo Fisher Scientific. Glyceraldehyde3-phosphate-dehydrogenase (GAPDH) monoclonal antibody was used as a loading control. Developed films were scanned 


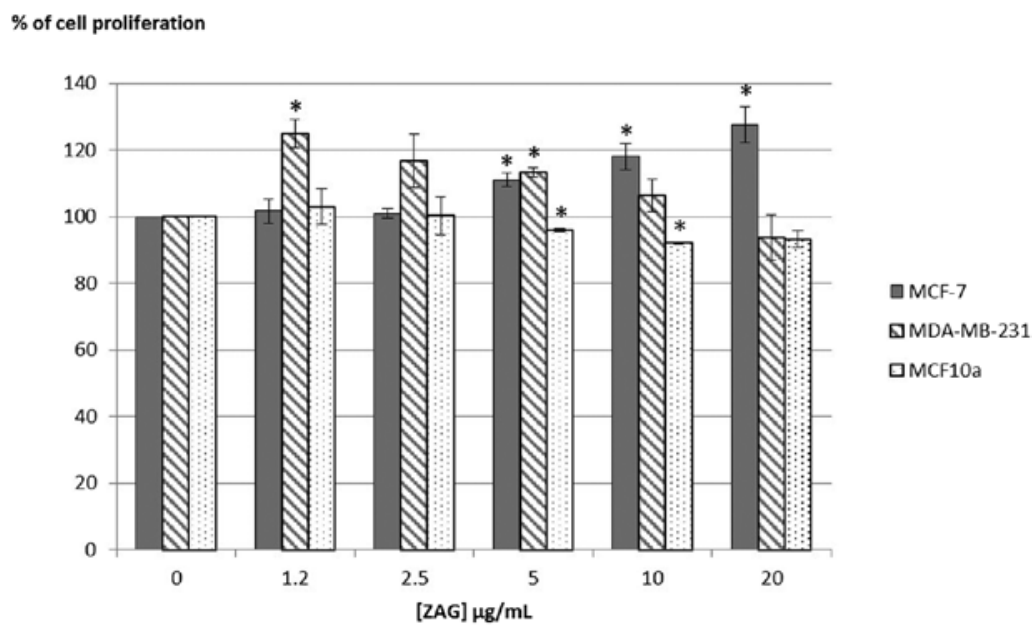

Figure 1. Effect of rh-ZAG on mammary cell proliferation. Cells were seeded in 96 well-plates with complete medium for $24 \mathrm{~h}$ and were then exposed to rh-ZAG $(1.2,2.5,5,10$ and $20 \mu \mathrm{g} / \mathrm{ml})$ for $96 \mathrm{~h}$. Bars are means \pm SEM obtained from three experiments. Significant difference compared to control ("P $<0.05$, t-test).

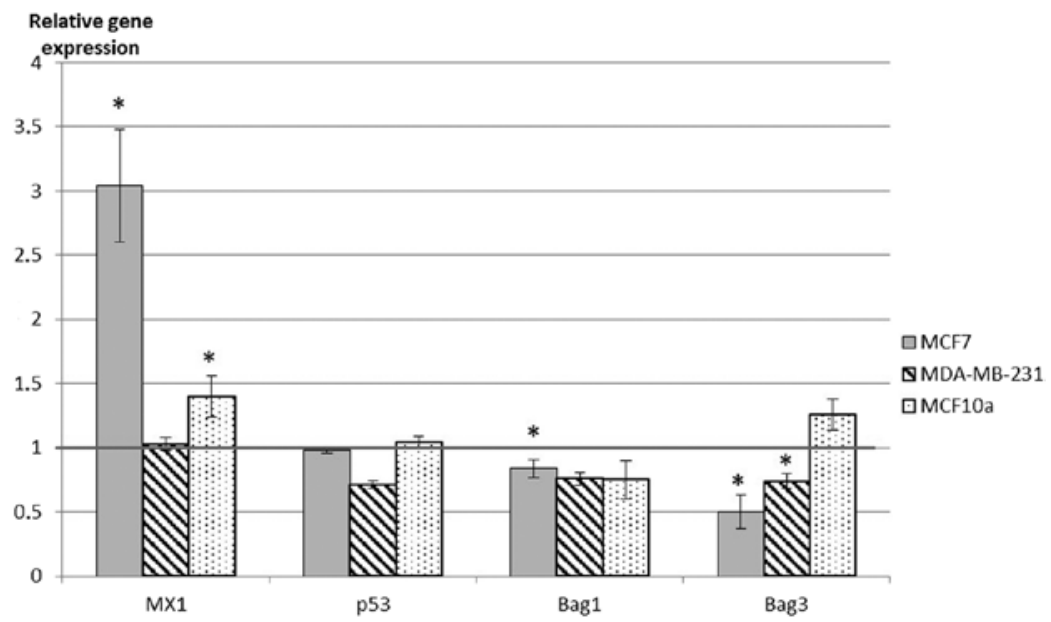

Figure 2. Effect of ZAG on mRNA expression in breast cell lines after $72 \mathrm{~h}$ of treatment. The gene expression of two apoptotic genes (Mxl and $p 53)$ and two anti-apoptotic genes (Bagl and Bag3) was evaluated in the three breast cell lines (MCF-7, MDA-MB-231 and MCF-10a) after treatment of rh-ZAG for $72 \mathrm{~h}$. The concentration of rh-ZAG used corresponded at the respective concentration points leading to an optimal effect on cell growth: $20 \mu \mathrm{g} / \mathrm{ml}$ in MCF-7 cells, $1 \mu \mathrm{g} / \mathrm{ml}$ in MDA-MB-231 cells and $10 \mu \mathrm{g} / \mathrm{ml}$ in MCF-10 cells. Significant difference compared to control ("P<0.05, t-test).

as JPEG images, and the pixel intensities within a band were measured with ImageJ software. The intensity of each gene was then reported to GAPDH intensity.

\section{Results}

Mammary cell proliferation. The proliferation of estrogen receptor positive (ER+) mammary cancer cells MCF-7 was increased at the highest concentrations tested [11 to $27 \%$ with $(\mathrm{ZAG})=5$ to $20 \mu \mathrm{g} / \mathrm{ml}$ (Fig. 1). In ER- mammary cancer cells MDA-MB-231, rh-ZAG had a proliferative effect at the lowest concentrations tested $[+24 \%$ with $(\mathrm{ZAG})=1.2 \mu \mathrm{g} / \mathrm{ml} ;+13 \%$ with $(\mathrm{ZAG})=5 \mu \mathrm{g} / \mathrm{ml}$. By contrast, rh-ZAG had an antiproliferative effect on fibrocystic breast cells MCF-10a when used at the concentrations of 5 and $10 \mu \mathrm{g} / \mathrm{ml}(-5$ and $-8 \%$ in proliferation decrease).

Gene expression. qRT-PCR was performed to study the effects of a 72-h rh-ZAG treatment on the expression of two pro-apoptotic genes (p53, $m x l)$ and two anti-apoptotic genes (Bagl and
Bag3) in the three studied breast cell lines. We used rh-ZAG at the respective concentration points leading to an optimal effect on cell growth: $20 \mu \mathrm{g} / \mathrm{ml}$ for MCF-7 cells, $1 \mu \mathrm{g} / \mathrm{ml}$ for MDA-MB-231 cells and $10 \mu \mathrm{g} / \mathrm{ml}$ for MCF-10 cells.

Bagl and Bag3 expressions were downregulated by rh-ZAG in MCF-7 and MDA-MB-231 cells, but remained unaltered in MCF-10a cells (Fig. 2). Concomitantly, Mxl gene expression was upregulated by rh-ZAG in MCF-7 and MCF-10a and more strongly in MCF-7 cells.

Protein expression. Fig. 3 shows the results obtained in cells treated for 24,48 or $72 \mathrm{~h}$ with rh-ZAG $(0,1,10 \mathrm{ng} / \mathrm{ml})$. In MCF-7 cells treated with rh-ZAG, an increase in $\mathrm{p} 53$ protein expression at $24 \mathrm{~h}[+100 \%$ with $(\mathrm{ZAG})=1 \mathrm{ng} / \mathrm{ml} ;+300 \%$ with $(\mathrm{ZAG})=10 \mathrm{ng} / \mathrm{ml}$ but a decrease at $72 \mathrm{~h}(-32 \%$ with $(\mathrm{ZAG})=10 \mathrm{ng} / \mathrm{ml})$ were observed. The expression of c-Myc was increased only at $24 \mathrm{~h}(+160 \%)$ whereas the expression of p21 and Bax slightly increased during the experiments (p21: $+21,+39$ and $28 \%$ at 24,48 and $72 \mathrm{~h}$, respectively; Bax: $+58,+37$ and $+64 \%$ at 24,48 and $72 \mathrm{~h}$, respectively). In MDA-MB-231 

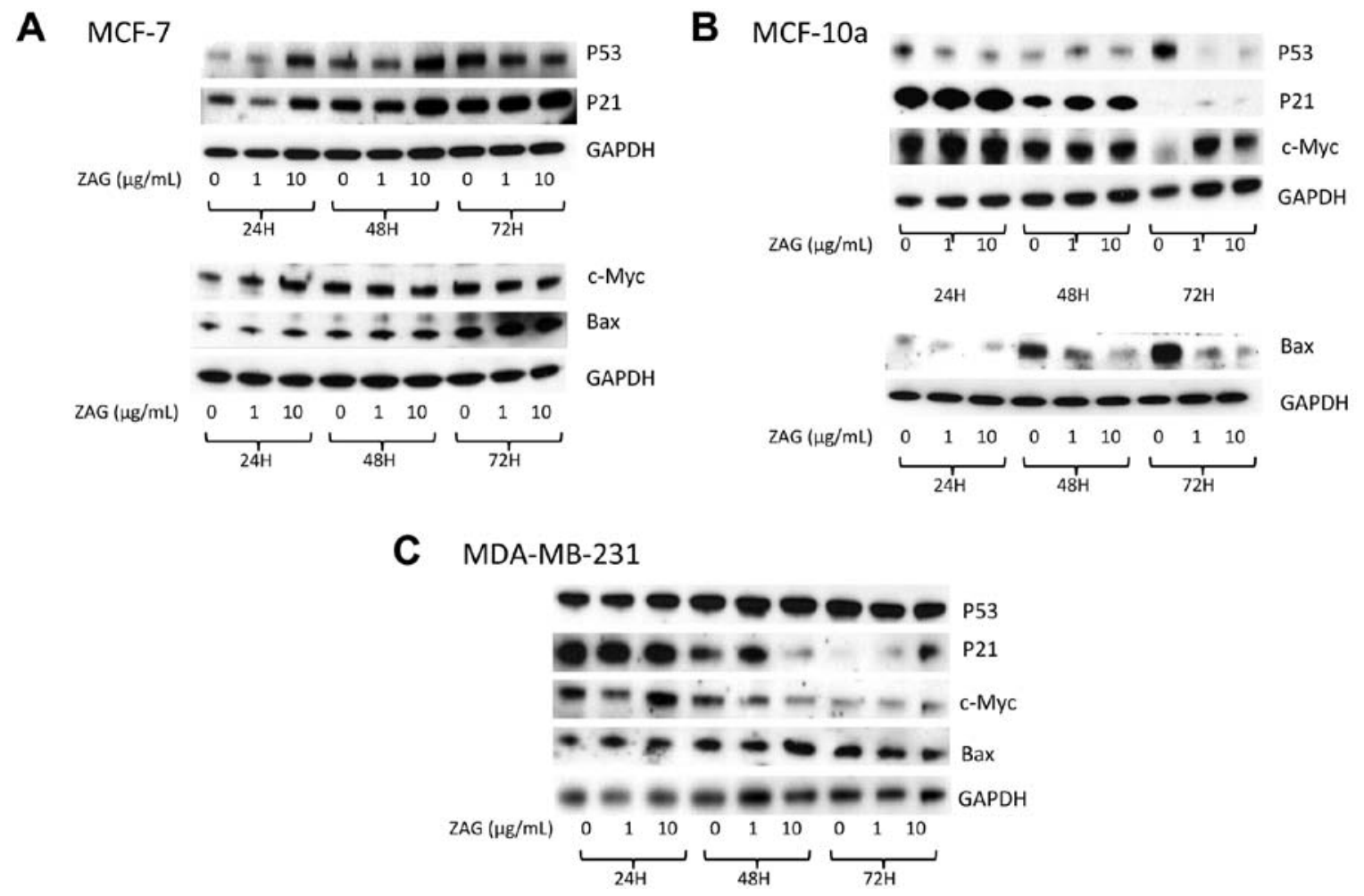

Figure 3. Effect of ZAG on protein expression in breast cell lines. The three mammary cell lines (MCF-7, MDA-MB-231, MCF-10a) were treated for 24, 48 or $72 \mathrm{~h}$ with rh-ZAG $(0,1,10 \mu \mathrm{g} / \mathrm{ml})$. The expression of P53, P21, C-Myc and Bax was measured.

cells, there was no evidence of ZAG-modulated variations in the expression of the different proteins tested. In MCF-10a cells, rh-ZAG enhanced c-Myc expression at $72 \mathrm{~h}[+80 \%$ with $(\mathrm{ZAG})=10 \mathrm{ng} / \mathrm{ml}]$ while downregulating both p53 $(-95 \%)$ and Bax $(-90 \%)$ protein expression at the same incubation time.

\section{Discussion}

ZAG, a well-known lipid mobilizing factor, which is downregulated in obesity, is now considered as an adipokine. We previously reported in vivo ZAG expression in breast malignant cells and in normal epithelial adjacent tissue (25). The present study showed ZAG had a proliferative activity on the two human breast tumor cell lines (MCF-7 and MDA-MB-231), but an anti-proliferative effect on MCF-10a cells derived from a non-cancerous fibrocystic tissue.

Tumor growth should be viewed as the result of a balance between cell proliferation and cell death. Our aim was to assess whether ZAG can regulate mammary cancer proliferation not only through an inhibitory pathway but also by triggering a programmed cell death. Markedly, ZAG had a proliferative effect in MCF-7 cells while upregulating pro-apoptotic Mxl and downregulating the gene expression of anti-apoptotic genes Bagl and Bag3. Such a modulation on apoptotic markers should result in a slowing process of cell proliferation.

Our data also suggest that ZAG-induced cell-growth inhibition in MCF-10a breast cancer cells could be mediated through the c-Myc pathway. Indeed, we found ZAG upregulates c-Myc protein expression in these cells. Despite its role in promoting tumorigenesis, there is increasing evidence that c-Myc also induces apoptosis in cancer cells $(26,27)$. Epithelial cells have also been shown to be susceptible to apoptosis by c-Myc (28). In addition, it was reported that MCF-7 breast carcinoma cells deprived of glucose exhibit both c-Myc elevation and significant cell death, which can be blocked by the addition of antisense c-Myc oligonucleotides (29).

We previously reported that endogenous ZAG was not associated with $\mathrm{Bax}$ and $\mathrm{Bcl} 2$ apoptosis biomarkers in breast cancer tissues (25). In the present study, we found exogenous ZAG did not consistently affect Bax expression in the two human breast tumor cell lines (MCF-7 and MDA-MB-231). By contrast, ZAG downregulated the expression of both pro-apoptotic proteins p53 and Bax in MCF-10a cells. We also observed an anti-proliferative effect for ZAG in these cells, therefore, apoptosis may not be the only mechanism to explain the resulting inhibitory effect on cell proliferation. In squamous carcinoma, ZAG inhibits cell proliferation by downregulating cdc2 expression and affecting cell cycle (30). In this study, ZAG did not affect the expression of the genes involved in apoptosis or differentiation (PCNA, p53, c-Myc and $\mathrm{Bcl}-2$ ). Of note, if adipokines generally modulate the apoptotic response in vitro, they may exert their activities through different pathways from one cell type to another since breast cancer cell lines display distinct patterns of apoptosisregulatory genes (31). For example, MCF-7 cells are caspase-3 negative, ZR-75 cells are $\mathrm{Bcl}-2$ negative and the p53 status is either wild or mutant, depending on the cell line.

Thus, our in vitro approach does not seem to reflect the complex regulation that may occur in vivo. Metabolic dysregulations associated with obesity (such as hypoadiponectinemia and hyperleptinemia) are likely to promote cancer cell growth via both systemic and local mechanisms. Furthermore, when 
mammary cells are engaged in the process of carcinogenesis, they produce adipokines (mainly leptin) able to act on surrounding cancer cells in a paracrine and/or autocrine manner. Adipokines act via their receptors on mammary tumor cells to i) influence tumor cell proliferation, migration and invasion in breast cancer; ii) regulate the production of epithelial-derived proteins, angiogenic proteins and growth factors; iii) stimulate other cells in the tumor microenvironment to invade and proliferate. For example, a study reported a proliferative effect of adipocyte-secreted factors on the MCF-7 breast cancer cell line, through the regulation of genes involved in cell motility, migration, survival, apoptosis and angiogenesis (32). In the same way, Celis et al (33) identified in mammary adipose tissue 359 protein components and excreted factors that may provide insight into the close interplay between mammary epithelium, stroma and fat tissue. Among these proteins, they identified several cell cycle regulators, including p53 and p21. Perera et al (34) used a proteomic approach and described for the first time the secretion of epithelial-derived proteins in MCF-7 cells in response to leptin. The secretion of such proteins in breast cancer cells in response to ZAG has yet to be reported.

In summary, these preliminary data show that recombinant ZAG has a pro-carcinogenic effect on breast cancer cells and conversely an anti-carcinogenic effect on non malignant breast cells. ZAG clearly modulates signaling pathways involved in proliferation and apoptosis but this modulation cannot fully explain the effects we previously observed with ZAG in breast cancer tissues.

\section{References}

1. Klein S, Wadden T and Sugerman HJ: AGA technical review on obesity. Gastroenterology 123: 882-932, 2002.

2. Lorincz AM and Sukumar S: Molecular links between obesity and breast cancer. Endocr Relat Cancer 13: 279-292, 2006.

3. Wolk A, Gridley G, Svensson M, Nyren O, McLaughlin JK, Fraumeni JF and Adam HO: A prospective study of obesity and cancer risk (Sweden). Cancer Causes Control 12: 13-21, 2001.

4. Chlebowski RT, Aiello E and McTiernan A: Weight loss in breast cancer patient management. J Clin Oncol 20: 1128-1143, 2002.

5. Daling JR, Malone KE, Doody DR, Johnson LG, Gralow JR and Porter PL: Relation of body mass index to tumor markers and survival among young women with invasive ductal breast carcinoma. Cancer 92: 720-729, 2001.

6. Belfiore A and Frasca F: IGF and insulin receptor signaling in breast cancer. J Mammary Gland Biol Neoplasia 13: 381-406, 2008.

7. Cold S, Hansen S, Overvad K and Rose C: A woman's build and the risk of breast cancer. Eur J Cancer 34: 1163-1174, 1998.

8. Pischon T, Nothlings $U$ and Boeing H: Obesity and cancer. Proc Nutr Soc 67: 128-145, 2008.

9. Fantuzzi G: Adipose tissue, adipokines, and inflammation. J Allergy Clin Immunol 115: 911-919, 2005.

10. Tilg $\mathrm{H}$ and Moschen AR: Adipocytokines: mediators linking adipose tissue, inflammation and immunity. Nat Rev Immunol 6: 772-783, 2006.

11. Perrier S, Caldefie-Chezet F and Vasson MP: IL-1 family in breast cancer: potential interplay with leptin and other adipocytokines. FEBS Lett 583: 259-265, 2009.

12. Rose DP, Komninou D and Stephenson GD: Obesity, adipocytokines, and insulin resistance in breast cancer. Obes Rev 5: 153-165, 2004

13. Schaffler A, Scholmerich J and Buechler C: Mechanisms of disease: adipokines and breast cancer - endocrine and paracrine mechanisms that connect adiposity and breast cancer. Nat Clin Pract Endocrinol Metab 3: 345-354, 2007.

14. Vona-Davis L, Howard-McNatt M and Rose DP: Adiposity, type 2 diabetes and the metabolic syndrome in breast cancer. Obes Rev 8: 395-408, 2007.
15. Jarde T, Caldefie-Chezet F, Damez M, Mishellany F, Perrone D, Penault-Llorca F, Guillot J and Vasson MP: Adiponectin and leptin expression in primary ductal breast cancer and in adjacent healthy epithelial and myoepithelial tissue. Histopathology 53: 484-487, 2008

16. Jarde T, Caldefie-Chezet F, Goncalves-Mendes N, Mishellany F, Buechler C, Penault-Llorca F and Vasson MP: Involvement of adiponectin and leptin in breast cancer: clinical and in vitro studies. Endocr Relat Cancer 16: 1197-1210, 2009.

17. Jarde T, Perrier S, Vasson MP and Caldefie-Chezet F: Molecular mechanisms of leptin and adiponectin in breast cancer. Eur J Cancer 47: 33-43, 2011.

18. Bing C, Bao Y, Jenkins J, Sanders P, Manieri M, Cinti S, Tisdale MJ and Trayhurn P: Zinc-alpha2-glycoprotein, a lipid mobilizing factor, is expressed in adipocytes and is up-regulated in mice with cancer cachexia. Proc Natl Acad Sci USA 101: 2500-2505, 2004.

19. Marrades MP, Martinez JA and Moreno-Aliaga MJ: ZAG, a lipid mobilizing adipokine, is downregulated in human obesity. J Physiol Biochem 64: 61-66, 2008.

20. Mracek T, Ding Q, Tzanavari T, Kos K, Pinkney J, Wilding J, Trayhurn P and Bing C: The adipokine zinc-alpha2-glycoprotein (ZAG) is downregulated with fat mass expansion in obesity. Clin Endocrinol 72: 334-341, 2010.

21. Bundred NJ, Miller WR and Walker RA: An immunohistochemical study of the tissue distribution of the breast cyst fluid protein, zinc alpha 2 glycoprotein. Histopathology 11: 603-610, 1987.

22. Diez-Itza I, Sanchez LM, Allende MT, Vizoso F, Ruibal A and Lopez-Otin C: Zn-alpha 2-glycoprotein levels in breast cancer cytosols and correlation with clinical, histological and biochemical parameters. Eur J Cancer 29A: 1256-1260, 1993.

23. Bundred NJ, Scott WN, Davies SJ, Miller WR and Mansel RE: Zinc alpha-2 glycoprotein levels in serum and breast fluids: a potential marker of apocrine activity. Eur J Cancer 27: 549-552, 1991.

24. Sanchez LM, Vizoso F, Diez-Itza I and Lopez-Otin C: Identification of the major protein components in breast secretions from women with benign and malignant breast diseases. Cancer Res 52: 95-100, 1992.

25. Dubois V, Delort L, Mishellany F, Jarde T, Billard H, Lequeux C, Damour O, Penault-Llorca F, Vasson MP and Caldefie-Chezet F: Zinc-alpha2-glycoprotein: a new biomarker of breast cancer? Anticancer Res 30: 2919-2925, 2010.

26. Meyer N, Kim SS and Penn LZ: The Oscar-worthy role of Myc in apoptosis. Semin Cancer Biol 16: 275-287, 2006.

27. Prendergast GC: Mechanisms of apoptosis by c-Myc. Oncogene 18: 2967-2987, 1999

28. Sakamuro D, Eviner V, Elliott KJ, Showe L, White E and Prendergast GC: c-Myc induces apoptosis in epithelial cells by both p53-dependent and p53-independent mechanisms. Oncogene 11: 2411-2418, 1995.

29. Lee YJ, Galoforo SS, Berns CM, Tong WP, Kim HR and Corry PM: Glucose deprivation-induced cytotoxicity in drug resistant human breast carcinoma MCF-7/ADR cells: role of c-myc and bcl-2 in apoptotic cell death. J Cell Sci 110: 681-686, 1997.

30. He N, Brysk H, Tyring SK, Ohkubo I and Brysk MM: Zincalpha(2)-glycoprotein hinders cell proliferation and reduces cdc2 expression. J Cell Biochem Suppl 36: 162-169, 2001.

31. Zapata JM, Krajewska M, Krajewski S, Huang RP, Takayama S, Wang HG, Adamson E and Reed JC: Expression of multiple apoptosis-regulatory genes in human breast cancer cell lines and primary tumors. Breast Cancer Res Treat 47: 129-140, 1998.

32. Iyengar P, Combs TP, Shah SJ, Gouon-Evans V, Pollard JW, Albanese C, Flanagan L, Tenniswood MP, Guha C, Lisanti MP, Pestell RG and Scherer PE: Adipocyte-secreted factors synergistically promote mammary tumorigenesis through induction of anti-apoptotic transcriptional programs and proto-oncogene stabilization. Oncogene 22: 6408-6423, 2003.

33. Celis JE, Moreira JM, Cabezon T, Gromov P, Friis E, Rank F and Gromova I: Identification of extracellular and intracellular signaling components of the mammary adipose tissue and its interstitial fluid in high risk breast cancer patients: toward dissecting the molecular circuitry of epithelial-adipocyte stromal cell interactions. Mol Cell Proteomics 4: 492-522, 2005.

34. Perera CN, Spalding HS, Mohammed SI and Camarillo IG: Identification of proteins secreted from leptin stimulated MCF-7 breast cancer cells: a dual proteomic approach. Exp Biol Med 233: 708-720, 2008. 